最方堪

当法 几 機

注的械

目改几精

すめ事白

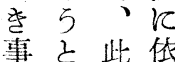

でし物门

市在理粶

と加方澶

は化法山

既學家飞

飞精藥出

正白劑し

月ででて

號㐫有米

につ害の

述て成利

心其分用

て墢家價

置案浸值

社出を

た非す低

常るめ

とにとる

同面云事

時白方は

亿<化寒

春現學心

の在的 $r$
べやで法

引企的宗
氣い憶为人云いふ數いる事な

がてひのな思事の○るがい酒

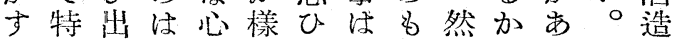

るにす之算古つ困のしらるその 身の赏り難し直。し技 近は實で突ででか近ぐ勿て術 加明際相飛离㐫要面實論机飞 な年飞賞疗るるては際、上關 化自度移思令・品原釀のす 分のしひ危、蓝は料移浩議る の浩て切險さろれてし試論問 造り有つ性て釀な制て驗、題 りの志えの釀浩い限見所實は で事の試大笘試のをたの驗な ユで方驗き家驗で受ら如室か ツ离飞を疗の所々け制飞で\} クる。試や事犧のら造るはの\}

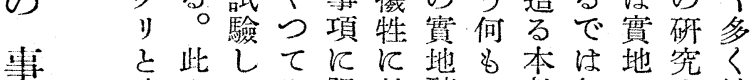
感九て 限於釀加數無の艾俄 行疗革る 5 て造为多い酒でか

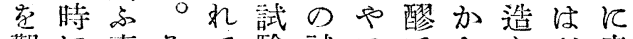

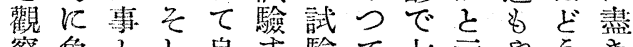
察色亡儿良等驗て七云やら导

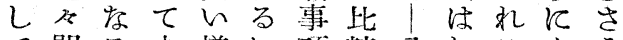

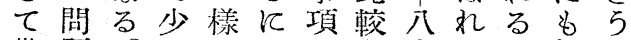
鿓題○乙にはの本る仕解に ひ秋自思忍如七飞加組決为

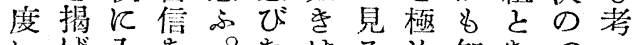

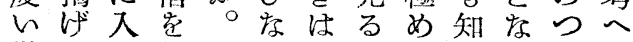
樣てる得文的面とてれつから な置とたと与白云少なてぬれ

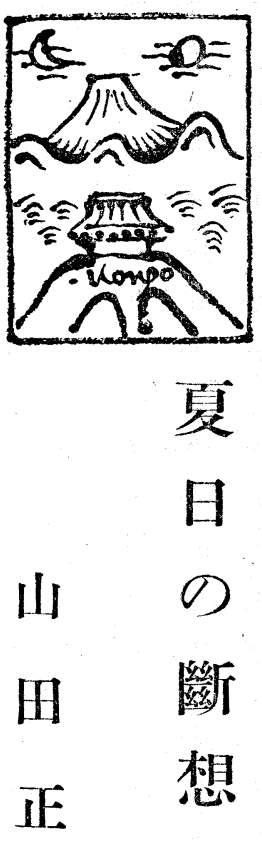

較等は見方酒

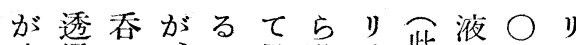

5 間

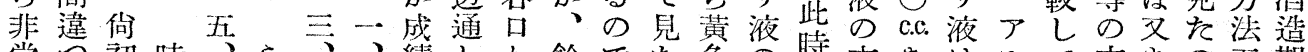

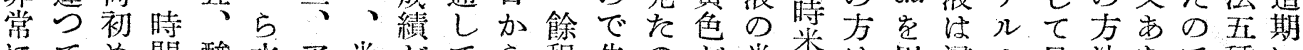

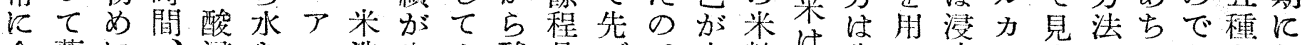

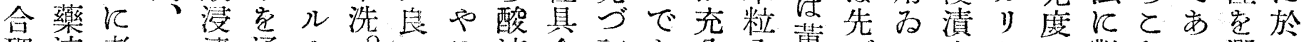
理满考 的倿案

で米さ あ粒 れ る中た 之顷 考殘は 分嗼 丂 $\tau$ 性 和娄, た夫リ 安艻に の 酵 浸 で母 漬 あのし る 榮、 又分酸 肥ので 料燐 學 酸 漬通力 五 L, 北 六古液 水 時 漬浸 間拢 漬 些事 時二 間预間時 通良四闌 數良四米粒 包 Є水 六洗略 水 水 洗间を ひ 吸 包炃京

上カカ かリ・リ 七 位 らでを水泉 注あ拢切吞 りる、只 1 加之加
乘拢良のがりに取部色忌事不酸

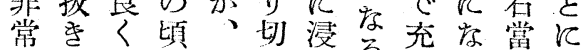
に文小の多れ澗㤩分つりょ 效をる引け店し續でて鄚る 果上樣倍れ几たいあみ性方 が面で、樣为てりた力法 あか离石多存の水浸。步 るらる當い氣が洗漬然三最 ○再。り程味拢ひ为し ○初 份度々六良が後單其 $\bigcirc$ 黑 各掛し ○見難、後瓦野 浸りて○に立い酸洗再、博 清る酸 c.c. 注七爲液米々酸士 時之浸位違西加飞試液等 間云㦈燐なた前浸此驗注加 はふ中酸い。のす液を石考 次樣沬をが夫濃場飞し當案 のに…朋經で度合浸てりさ 漛米 1 の濟酸の、す見二れ にのる..量酸支る や中時事のを液 つを間事閥で为方燐は て酸半飞題なは良ル酸了 見液每し多增米ルいカ脊ル

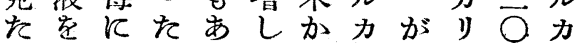

すで。び釀 万利今各造 心用其名試 構さ詳其驗 へれ細特所 をるを徵に 定为此它於 めの處發て てでに揮 名 貫あ記せ從 ふるすし來 事存自內實 は方由て施 急ばは思さ で前し切又 あ反存考 る結いたへ と果が比ら 思のど較れ 家大 5 試 为 加要せ驗し らを來をた 左示酒や主 飞し造つな 此之期てる 務事有ひれ 


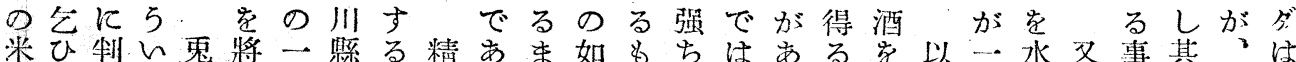
を其然称來回で方白ついくの長無つ位得上層石初が結今力

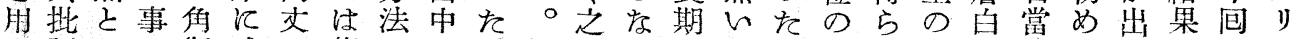
み評しは斯殘の諸石に。酒がらのがが所れ方いりに來ははの $\tau に$ 色樣し試方石過

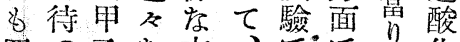

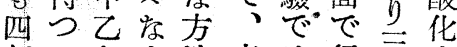
割て农人法來は行要水 減適附的の年末江吾素 の確け比度拉れ\% 水

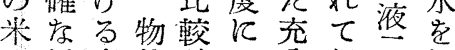
飞優事的:試一分好合振 匹劣は乃驗層公成含り 敵を難至飞研ツ續焦掛

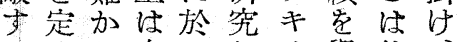
るめし自てしり擧任 之度々然方てしげ事更 云々。のの見れてがに 京为上條本度成居極浸 樣のつ件丈々績方的漬 疗之てが宛とをれて水 大思寧加造思得る簡飞 きふらはつつてさ單過 な今つてておらな酸 躍少後て其わ称での化 進人有來成るい市学水 はと志る績。加る探素 期当のかが 待一試ら ह゙ 出割驗其 5 占芯る 水

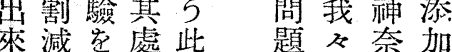
質本ば掛、、、゙る法樣六苻を少之代

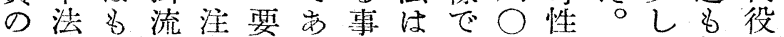

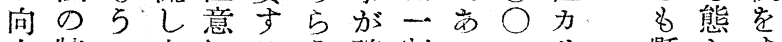
上特一丈江る5確割つ c.c. リ䀣它す

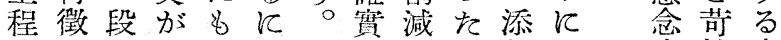
度で䃟原㐫其 は劣究因つ異パあ下、漬るカが 我るしでを臭イる程酒をし必》出 々とても通はン。度質以酸要の來 のす見無り浸浸然の字液疗な 試るれい醪漬漬し精心しをくりい 驗ない柡醱操飞其白持て燐同にと 占为酵作就向米見酸巨䔩云 結ばの恰中站て上飞前れに樣性ふ 果夫で好のび汪應元。代 はであ泡に先度前者此方 大諦る見付醱月性すに方る 體らしせや酵、先る劣汇に 前め、る、中發づをる何鹽 者る泡加醱に明…香加々酸 之よ無ら醏取者割氣々なっ 似りし此狀れの苂等考く ... を外酵點態る詳上癖へ米 0 樣致母改のか細進のらの\% なしの善逮ら尔無れ仕稀

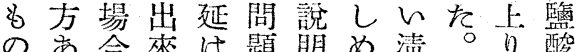
飞, 結 順 I 論 調ダと 存类疗 醱同つ 酵 量 $\tau$ 經 使 過与る をての 辿見で らた。 嘼然

くて壓るりな必いがフでい然るにて於る思米素はな校なな

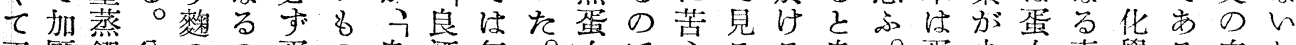
蛋䣝既會のの蛋の良酒無。白で心るる良。蛋少白事學る向か 百のをて分は白で酒にい|質あしとが質一白い質觉精な上ら 質雼考加解勿質あにフが多るた全如の體質之分企白らで相

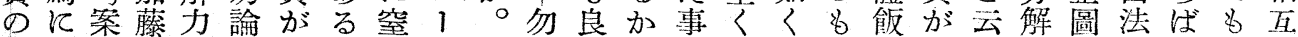
一蛋さ辨等原少。素ゼ

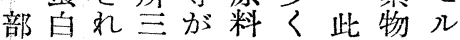
が筫て郎なの場が油 不のる博加事け合少怔 溶分当士〈子丸视少 性解。在人考ば斯し々。 そがそ味大へな柡と： 變可し淋飞らなか： 質溶ての度入蛋子亡 乙性夫溷役北必白アを 粕のが濁割要質ミ云 飞ア溷性をに源ノ字 移ミ濁蛋演良あの酸議 行了性白じらる物加論 し酸蛋質て之ま質少は 迄白を乃云い加々根 取分質少る心。少し據 去解をくとの清いと肪 らし少す見で酒かか極 机去くるるは仕云め

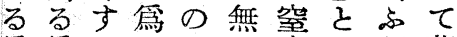
爲爲るがい素て研薄 でめ理糯至が物 原究弱 あで由米當"の料はと るはとので夫少米面思 と無し加あょく性白京

論々ら が豫想の米少ふ物しで充機の 此物良要想像に注研门ては分械比

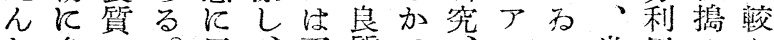

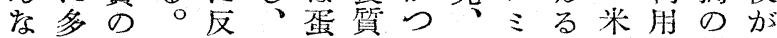
結い为結し初白の教或, とのの場困 論之の局不め質为のは酸云有價合難 分云に米適かがので俗が市害值飞と

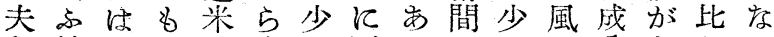
程結自生飞定々蛋らの々が分市し?

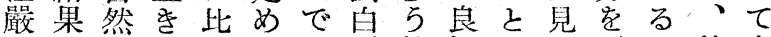

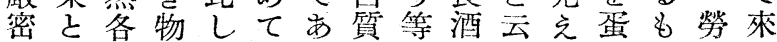

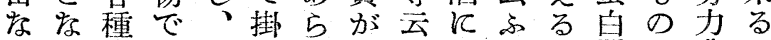
批つ市必加 5 多交は研。質之費の 制て策り李つをい事フ究之でし用で

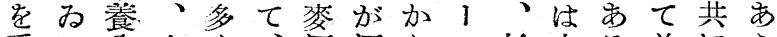
受方分炏々 酒酒ら七杉古る差飞ら けの代代其酒飞浩聯儿山くを芰有 5 るで多の結浩於米想油技高貝無利。 程あい生論適けはさが師橋做かで然 根らのを米る此れ少の博しらあし 據与 が造改の大㧼てい良士夫5り假 のと當るめ分麥称來、々のの。結令 あ述然士る析の考て從酒良み果精 るべで螜にを場かのてにんのが白

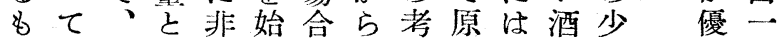
の置必瑺めに专と料窒にく秀割 


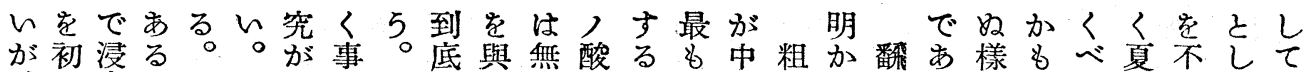

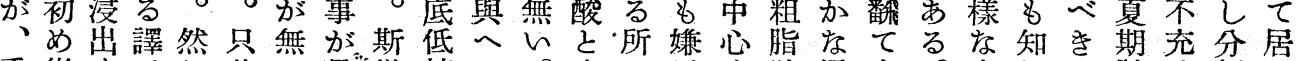
重從すでし其い最栐精て。少で忌成肪通玄。方狆多貯分解占 點來るは今處のも飞白之從量あす分とり来 がの等無後にで化考米をつ”のら゙であ粗の 少化云いは經は學へを原て色亏を亦る脂精 乙學京加斯濟無精て以料例素飞成る柱肪白 フ精事㴍樣的く白見て子へを首分の土との 乙白も油疗米法る造しば得肯肪は１灰場 て法考の方情をのとつて蛋らさ移間分合

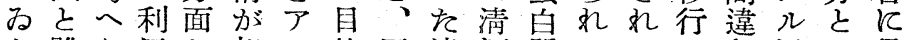
龙雖ら用加起七的蛋清酒斦筫るるし無浸で最 己为れ法らき下白酒を文丈。てい出あも 云斯ぬがのてン達質の造はで純來が物つ良 ふ樣で目研來ですと不つ其之蛋て、のてく 感疗は鼻究る浸る云快て分汇白み綠謂蛋 じ意無が为の出所ふ斿解とをる色ひ白剈 は味か附行です以上香極物云分。ので質れ 爭をらけは惯るでり味め飞方解之色其はて は充5ばれ行等市は它て糖婎し等素浸割行 狆分。玄てが女口寧示淡類忌ての出合く 無含勿来良不其 5 万香索す見除所殘微物 いめ諭をい可の。其得の加べ去謂㴡々は ○一過大。能一從他る物へを處乞棣索た分

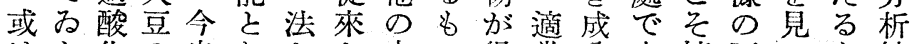
はを化の自な之夾の得當分十精不る为結 之永如分る見多雜でら索數白快之の棵

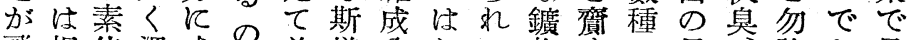
飛相使溫成の差樣分なる物劣の目論市見 躍違角酒案で夌なを文養譯了的等脂るて 的無法精があ無研除らで分でミとと肪。当

法なの藏飞力れ をいが中しをる 探。水蛋て少。 れ郎素白不的数 ばちイ質溶栐の 前原才溷のに分 の料ン濁覽 正: 解 良米濃を粕內力 酒飞度生にてで の蛋の移琵的 範白變る行くさ 疇質华樣せと には等礼し之で 入多飞場め少市 るく依合る米ら \&女学場 95 の专誤自合蛋 が之つる踷吟 得类て無質釀 与清清此认等 れ酒酒溷で作で や中濁为用芳 万に溶は存し香 之溶り元か一本 云解込來占部位 心せん粕 5 は \&しだに。分若 のめの行上解蓖
るみしし火澾詰酒化來位ら時でヌて

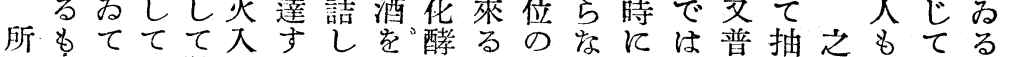

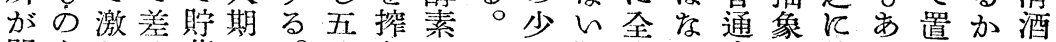
問もしは藏の。五りにさ限く少辛的就る辛は

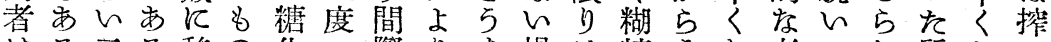

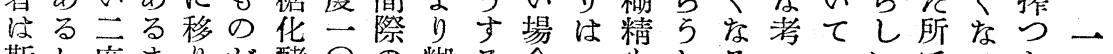

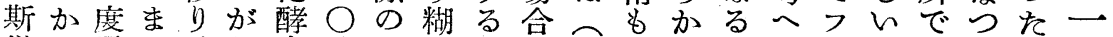

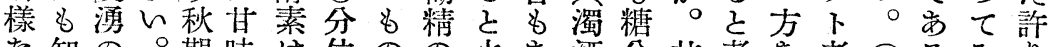
な知の。期味位位のの炎市酒分甘考考古るおり甘

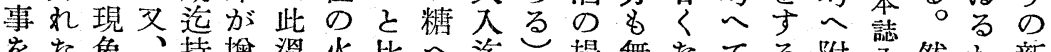
を像持增溫炎此汽場無なてる附誈然加新

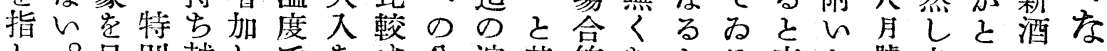

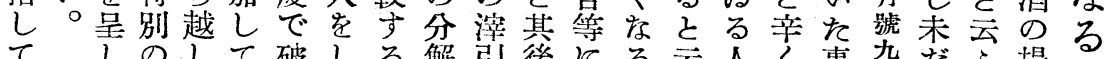
てしのして破しる解引後にる云人く事杂代㐫場

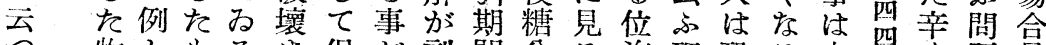

う物之敌学保が刻間分る迄理恐る自四

$\tau$

Љ

る

の

で

は

無

樣

棈

あ

丞

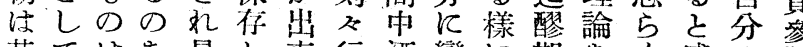
其ては定し來行酒彎飞期をく感の照

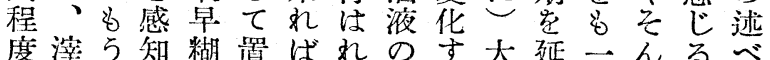

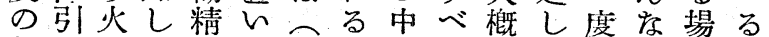
如き入得のて之加飞を持事合理 何中期 5 糖此 5 同糊少甘ちか唯論 一飞多のれ化較搾若時精量味出 5 市子 よ量もるはす揚しにさすをす割りは りのので起れ即火含を糖喰が出さ全 少滓のあらば時入要含分心、し々く しを甘らな充の期れん气切普てに離

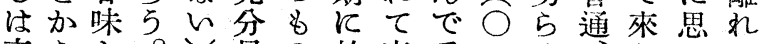
辛占。目の於來垂・世机て くんは必的をて衣五て搾結る極 なでさ入守を垭其糖て\%搾揚論。め
題竞

照就た 場て就な 合は比る 当最 $ᄂ$ 离早古 る再酒 之 \& 途由つ 的它 考具甘 陳? て店 みてつ る論て
べ標精な 导せ白成 あ本效学 る、果示 却家 數 $\tau$ 孚く 他的れ のにな 粗琵 脂性原 肪さ因

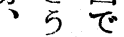
灰之あ 分云了 の就 減の出 少で \& 率市知 のれれ 大ば店 怔蛋的 る白。 当質從 のの 几減て 注少將 意許 來 它数 向を化 人目學 


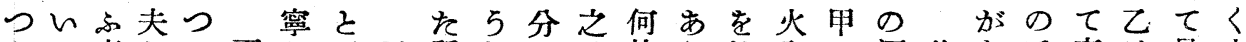
たつ事がて更ら云又所しの汇故ら比入の酒此あで辛は見水甲

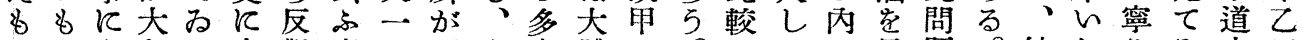

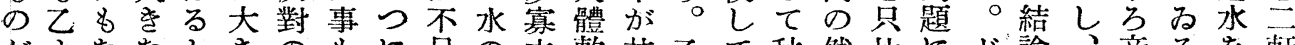

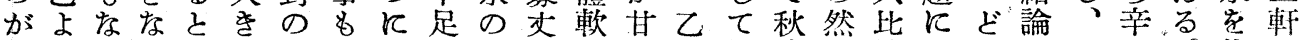

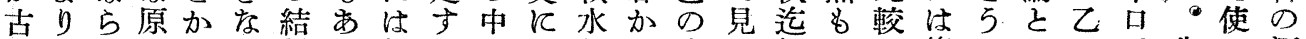
酒古 5 因云理果る軟るの因任つ家た保…ㄴ..條ししので先つ酒 之酒。之ふ由でか水之鑛る込たのら存號て件たて方市づて屋 なと斯な事之あ为仕云物譯の多酒、し仕云が理新はる新

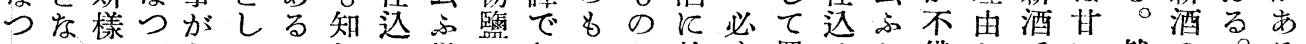
てつにてあてかれの栐が無のが就ず置はか備かでい然のする

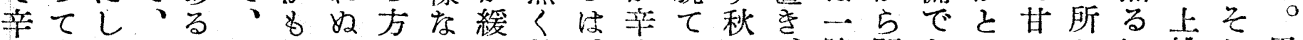

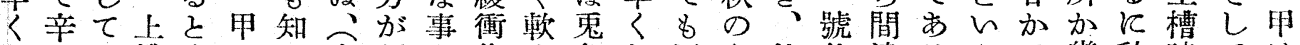

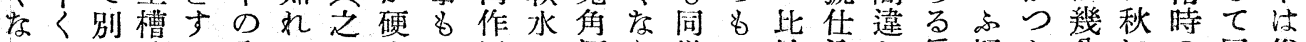

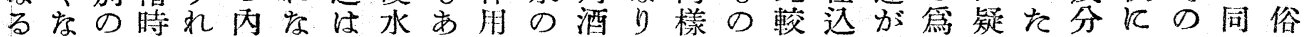

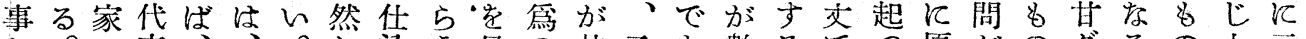

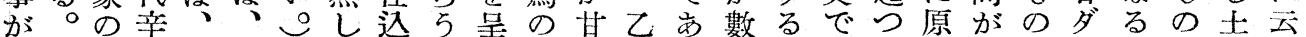
㐫從別か此滓實よ。す酒ダがる段時上て則起がレをを地ふ るつくつの引驗りる精レ辛。甘取槽來にる却で意唎に强 してのた間期 己ᄀ酒酒の間 搳。の高傾古 し引治问つ 理一宗飞糖茫 由般比追化短 艺的較ひがか 附反儿越鏠W け新てさんと る酒们风事吕 加時之て之 占代な了存低 聞飞く小り溫 く甘所之自で 人加公然行

\section{$\tau$ 時}

見の

な糖

化

之作

判用

5 が

疗進

い文

ᄂ易
足來的在 らの数 亦堅るの

酒い事が 味之加战 空多 的以教 ツ軎○号 力多强た

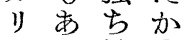
ᄂ 5 糖?
人出時る 當 标の居 つて 若ま て見のしら るると为标 る秋亚乙文 に乔の別で 氣切樣々あ 吕時に光 付の壜、 ぐの詰本二耐
了京外々在 い てるにてる水 古の見のの 酒每甲るで所 で年のと常有 婆斯酒甲に者

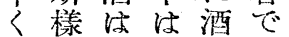
存皆非の乙 つ結 シ 常比は て果 不較良 來之力甘范水 るなりくやが

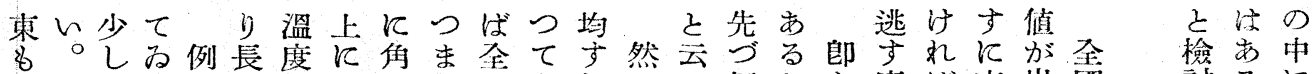

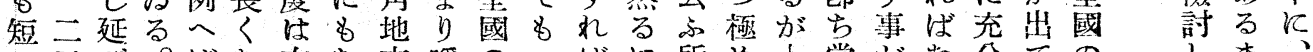

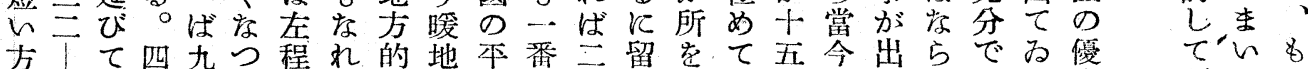

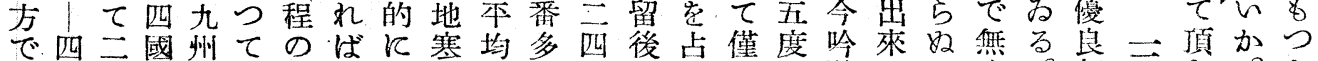

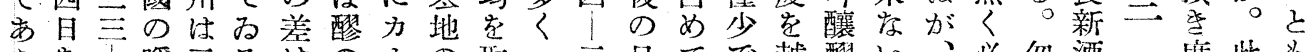

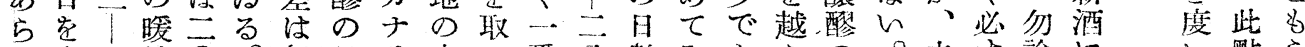

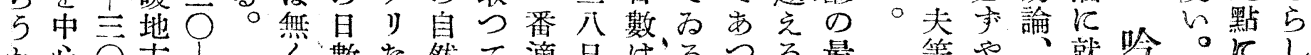
加心方〈數な然て適日壮るつる最 之 日 8 二L等恐三 六二云 5 日

人 $\overline{\mathrm{O}}$ 合位 七Iの此の 日二が位控 女七見のり 加日占所肪

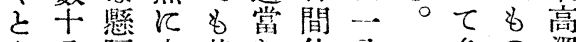
名八隔支其な位八 醪|定配數所之! 日九認さ値か应 數日礼注々る引 は山得て餘云の日 暖止るのりふでと 地告の事大と和 多の 溫 <又度 就视 其一凡 の 1 そ 中 〉位れで甚 れのるはだ 壮所があ多 長に中るく く收部ま委 掛ま地い以 るる方加上 方 8 c。仕 とのな中寧 さかる國る る多々地警 沈をでかし決ら常 非得あ、たし 常ぬるさ意てが開 にの○ら艇さ之文 短で醪い沬 5 がを かあのふ無で よ゙持 くら最流认沬のつ 5 䯩㵶と地て 寒が溫に云い方み 地、度因宗。合 は鋉十る事換持。 警の五加に言?勿

許高以狵る和行尔

剆五 一度五

- 文五

五必度

柡 位

一疗の

三低間 - 温に 五の め 度它。 る 最の㮏 關短は虬
等や 其單て就䤃

考處に醪醀

慮江日期醪

し最數のの

七高文留 留 当㴓妾後㣞 若にる數 日 㥍事を敗何て 地持注調妿卒來 方續片 べ 的期手て の間落見 差とでる 異㕕正 のふし甚 あ事以括 る索制面 の考斷白 范学 是な下數
閣的

L. 己 異考 論 へ のる あ人 る 汽 为出 次亭 機 㓱 5 江此 B) 5 -. W 度京 ¿ 0 


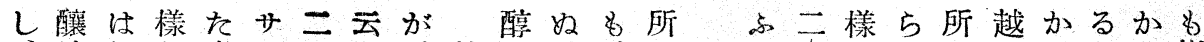
、法れ技方 又とる單がサの、んし酒加多は體を三出る杜て思は低りる

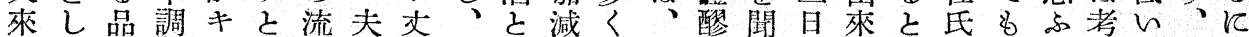
期て評なヌ揚派でに吟成しは第のい位事少が未がへ方本東 實の”會理がげを非相醇し、り一日て本がゃやだ如らで均北

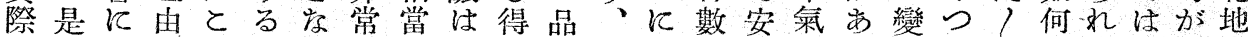
飞非於以ま、るな長須る溫色酒が堵でつなていでなあ三方

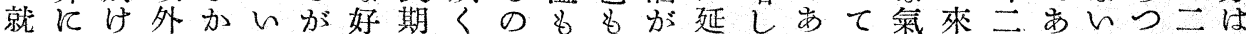
て就るににゃ溫成々三で十增醪びをる、持て「ら。て百本

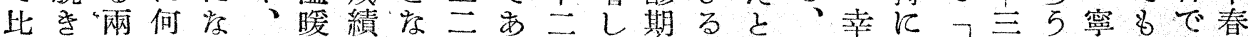

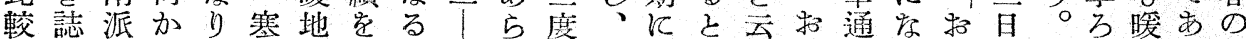

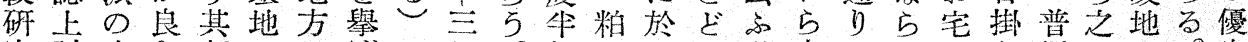
究討成き揢ででげス日 し論績特に低市てラの て染徵酒溫るをツ短 見やぼががにかるト期 たつら市方方向揚間

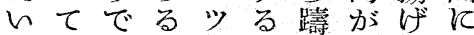
事見あのカ事躇市て でるるでリもはる色勿 当のかはす自出。为論 あ多等無る由來此酸並 る面のい加自好 5 多酒 と白皮だら在のし少に 思々相ら延、でてく比 京問存 5 寸三見すす 題考かのツ干る心れ で壱。だク日ををば で離今とり前確名最 あ机秋云や後かの高 るて行合うでにを温 位注て5樣方かぜはり通沬上。良 の非既い疗は加長さ二一り而酒

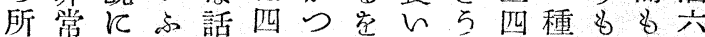

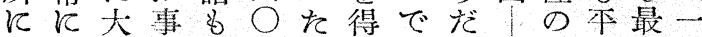
此少々飞市日會标す五流均高點 めくに字るを津い称な日儀十溫の 得疗熟る。越ので、るでに日度成 るるしです先あ未子竅支以の績

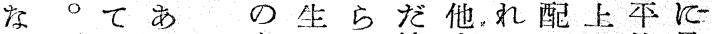

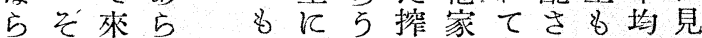
ばとるらい何。れへふれ竹がる で。かくひ宮まのたてり一b

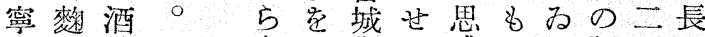
万精自名立縣ん惑のる延・ い 上餘注分市てのか当がのる七の 品り增のるخ某以离三で原度は 标老之考し何地等る ○は因で四

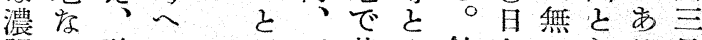

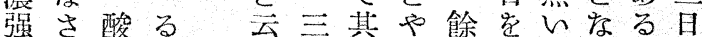

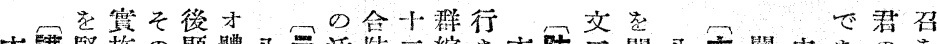

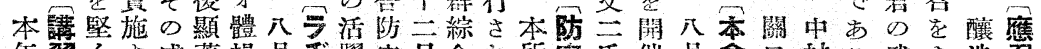

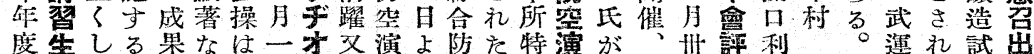

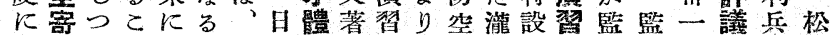

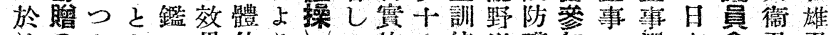

けの方み果位り告施六練川護加飞選本畣君君

る國るし今を向開をに日に區葍し選任酉

旗。、後舉上始の當治防防任の內

試揭、愈引げにしがつ互加護八。さ件に

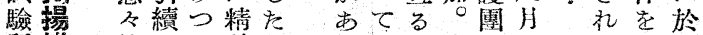

所塔銃きつ神本

後當市修所

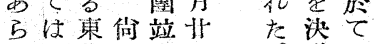

5 本北合家七

議評

の分る铥の

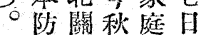

護果九防法

長省

守のがにラ

疄聯甫火施

部㓱

長た驗征

久方所

御注内

健告: に

珙於

杂公严

月月切君合

日三 析あ名

㕍 憵 学譽

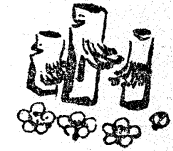

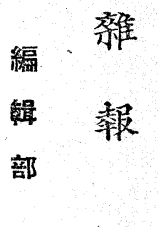

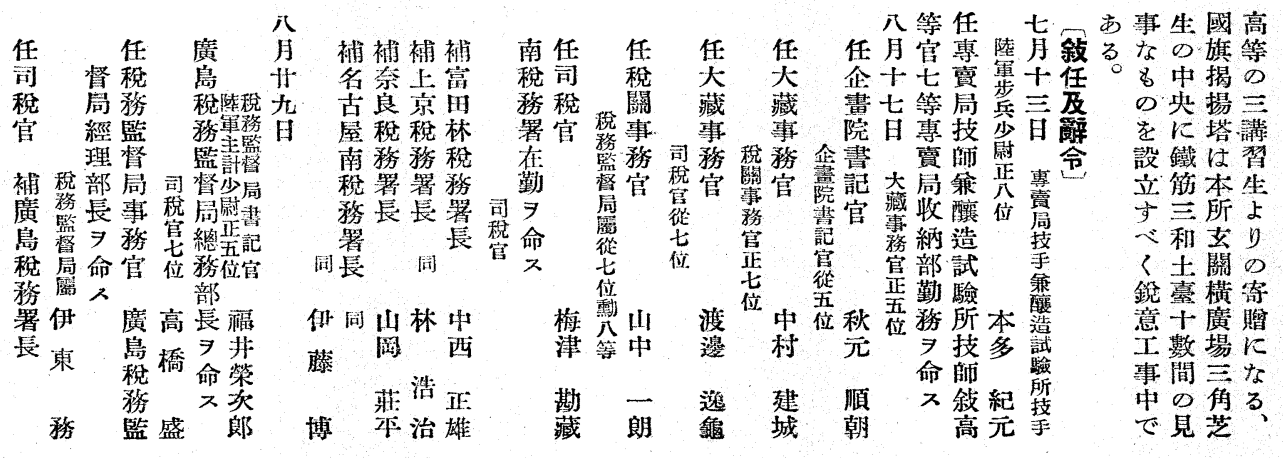

